2016-02

\title{
Dietary administration of a commercial mixed-species probiotic improves growth performance and modulates the intestinal immunity of tilapia, Oreochromis niloticus
}

Standen, BT

http://hdl.handle.net/10026.1/4258

10.1016/j.fsi.2015.11.037

Fish \&amp; Shellfish Immunology

Elsevier BV

All content in PEARL is protected by copyright law. Author manuscripts are made available in accordance with publisher policies. Please cite only the published version using the details provided on the item record or document. In the absence of an open licence (e.g. Creative Commons), permissions for further reuse of content should be sought from the publisher or author. 


\section{Accepted Manuscript}

Dietary administration of a commercial mixed-species probiotic improves growth performance and modulates the intestinal immunity of tilapia, Oreochromis niloticus

B.T. Standen, D.L. Peggs, M.D. Rawling, A. Foey, S.J. Davies, G.A. Santos, D.L. Merrifield

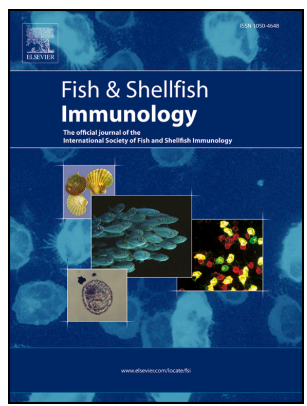

PII: S1050-4648(15)30256-4

DOI: 10.1016/j.fsi.2015.11.037

Reference: $\quad$ YFSIM 3719

To appear in: Fish and Shellfish Immunology

Received Date: 13 July 2015

Revised Date: 30 October 2015

Accepted Date: 29 November 2015

Please cite this article as: Standen BT, Peggs DL, Rawling MD, Foey A, Davies SJ, Santos GA, Merrifield DL, Dietary administration of a commercial mixed-species probiotic improves growth performance and modulates the intestinal immunity of tilapia, Oreochromis niloticus, Fish and Shellfish Immunology (2016), doi: 10.1016/j.fsi.2015.11.037.

This is a PDF file of an unedited manuscript that has been accepted for publication. As a service to our customers we are providing this early version of the manuscript. The manuscript will undergo copyediting, typesetting, and review of the resulting proof before it is published in its final form. Please note that during the production process errors may be discovered which could affect the content, and all legal disclaimers that apply to the journal pertain. 
1 Dietary administration of a commercial mixed-species probiotic improves

2 growth performance and modulates the intestinal immunity of tilapia,

3 Oreochromis niloticus

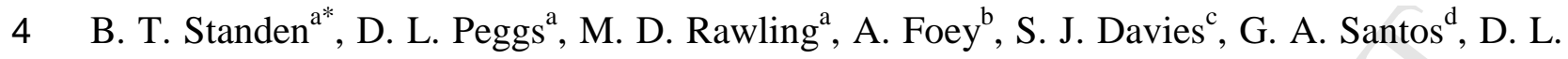
$5 \quad$ Merrifield $^{\mathrm{a}^{*}}$

$6 \quad{ }^{\mathrm{a}}$ Aquaculture and Fish Nutrition Research Group, School of Biological Sciences and ${ }^{\mathrm{b}}$ School 7 of Biomedical and Healthcare Sciences, Plymouth University, Drake Circus, Plymouth, 8 Devon PLA 8AA, UK.

$9{ }^{\mathrm{c}}$ Department Animal Production, Welfare and Veterinary Science, Harper Adams University, 10 Newport TF10 8NB, UK.

$11{ }^{\mathrm{d}}$ Biomin Holding GmbH, Industriestrasse 21, 3130 Herzogenburg, Austria

$12 *$ Corresponding authors: benedict.standen@yahoo.co.uk; Daniel.merrifield@plymouth.ac.uk

Abstract

The growth performance, immunological status, intestinal morphology and microbiology of tilapia, Oreochromis niloticus, were investigated after dietary administration of the commercial probiotic AquaStar $^{\circledR}$ Growout. Tilapia $(29.02 \pm 0.33 \mathrm{~g})$ were split into five treatments; control (CON), $1.5 \mathrm{~g} \mathrm{~kg}^{-1}$ probiotic (PRO-1.5), $3 \mathrm{~g} \mathrm{~kg}^{-1}$ probiotic (PRO-3), pulsed probiotic feeding (PRO-PULSE) or an initial probiotic feed followed by control feeding (PRO-INI). After six weeks of experimental feeding, fish fed PRO-3 displayed significantly higher final weight, weight gain and SGR compared to the CON or PRO-INI treatments. Supplementation of the probiotic at this dose induced an up-regulation of intestinal caspase-3, 
24 pathways were also affected; significantly higher expression of TLR2, pro-inflammatory genes TNF $\alpha$ and IL-1 $\beta$, and anti-inflammatory genes IL-10 and TGF $\beta$ suggest that the probiotic may potentiate a higher state of mucosal tolerance and immuno-readiness.

27 Histological appraisal revealed significantly higher numbers of intraepithelial leucocytes in 28 the intestine of PRO-3 fed fish compared with treatments CON, PRO-PULSE and PRO-INI 29 but not PRO-1.5. Additionally, fish receiving PRO-3 had a significantly higher abundance of 30 goblet cells in their mid-intestine when compared with fish from all other treatments.

31 Together, these data suggest that continuous provision of AquaStar ${ }^{\circledR}$ Growout at $3 \mathrm{~g} \mathrm{~kg}^{-1} \mathrm{can}$ improve tilapia growth and elevate the intestinal immunological status of the host.

Keywords: probiotic; tilapia; fish; immunity; gene expression; growth performance; histology, intestinal microbiology.

$37 \quad 1 \quad$ Introduction

38 Aquaculture continues to be the fastest growing animal protein production industry [1]. As a 39 result of extensive research, probiotics are becoming an increasingly popular choice as a 40 prophylactic approach to avoid disease and improve health and production of farmed fish, 41 including tilapia.

42 A number of probiotic investigations have focused on growth benefits in tilapia, with many studies reporting positive results after probiotic supplementation [2-8]. As well as strong growth performance, it is important that fish are healthy and capable of mounting an effective immune response when exposed to pathogens. The gastrointestinal (GI) tract plays an important role in the mucosal barrier function. Not only does it serve as a physico-chemical 
47 barrier against invading pathogens, there are also tolerance mechanisms in place which allow

48 the residence of commensal and mutualistic microbes [9]. Probiotics can have beneficial 49 effects on the gut-associated lymphoid tissues (GALT). These benefits can manifest 50 themselves within the intestine by means of reinforcing barrier defences by elevating 51 populations of intra epithelial leucocytes and goblet cells and also by inducing the expression 52 of pro-inflammatory cytokines (e.g. TNFa, IL-1 $\beta$ ), thus maintaining the capacity of recognising and responding to pathogens, and regulatory cytokines (e.g. TGF $\beta$, IL-10) for the maintenance of mucosal tolerance [10-15]. These cytokines are the end products of complex molecular pathways which are initiated by toll-like receptors (TLR's) recognising their corresponding microbe associated molecular pattern (MAMP) [16]. Probiotic supplementation can up-regulate the expression of intestinal TLR3 in Atlantic salmon, Salmo salar, and intestinal TLR2 and TLR5 in grouper, Epinephelus coioides, with a corresponding induction of intestinal IL-1 $\beta$, TNF $\alpha$, IL-8 and TGF $\beta$ expression $[17,18]$.

60 Currently, there are multiple probiotic formulations commercially available. It is essential that probiotic candidates are evaluated for efficacy and the dosage and feeding regime should be optimised [19]. The current investigation aimed to evaluate multiple doses and feeding regimes of a commercially available multi-species probiotic, AquaStar ${ }^{\circledR}$ Growout (a mix of

64 Bacillus subtilis, Enterococcus faecium, Lactobacillus reuteri and Pediococcus acidilactici at

$651 \times 10^{9} \mathrm{CFU} \mathrm{g}^{-1}$ ), on tilapia growth performance, intestinal integrity, intestinal microbiology and intestinal immunity. 


\section{ACCEPTED MANUSCRIPT}

\section{$2 \quad$ Materials and methods}

71

72

73

74

75

\section{$2.1 \quad$ Experimental design and dietary preparation}

All experimental work involving fish was conducted under the Home Office project licence PPL30/2644 and was in accordance with the Animals (Scientific Procedures) Act 1986 and the Plymouth University Ethical Committee.

Three iso-nitrogenous and iso-lipidic diets were formulated using Feedsoft Professional ${ }^{\circledR}$ according to the known requirements of tilapia [20] (Table 1). Dry ingredients were mixed in small batches to ensure a homogenous mix before adding the oil and warm water in a Hobart food mixer (Hobart Food equipment, Australia) to form a consistency suitable for cold press extrusion (PTM P6 extruder, Plymouth, UK) to produce $2 \mathrm{~mm}$ pellets. The lyophilised probiotic (AquaStar ${ }^{\circledR}$ Growout; Biomin $\mathrm{GmbH}$ ) was added at the expense of corn starch and the basal diet void of the probiotic served as a control diet. Diets were dried for 24 hours in an air convection oven set to $44^{\circ} \mathrm{C}$, broken up by hand and stored in refrigerated air tight containers prior to use. The dietary proximate composition was analysed using AOAC protocols [21] (Table 1). Probiotic viability was checked using selective media (de Man, Rogosa and Sharpe (MRS) media, Bacillus selective agar and Slanetz and Bartley media for Lactobacillus/Pediococcus, Bacillus and Enterococcus spp., respectively) by spread plating 10-fold serial dilutions and counting statistically viable plates (i.e. 20-200 colonies). Fresh diets were produced at the trial midpoint to ensure high probiotic viability.

Nile tilapia, Oreochromis niloticus, (Fishgen Ltd., Swansea, UK), were transferred to the Aquaculture and Fish Nutrition Research Aquarium, Plymouth University, UK where they were allowed six weeks of acclimation. Five hundred tilapia were randomly distributed to ten 150L fibreglass tanks (50 fish per tank; average weight $=29.02 \pm 0.33 \mathrm{~g} ; n=2$ ). Treatments were as follows; control (basal diet void of AquaStar ${ }^{\circledR}$ Growout), low probiotic dose 
94 (continuous feeding of the basal diet supplemented with AquaStar ${ }^{\circledR}$ Growout at $1.5 \mathrm{~g} \mathrm{~kg}^{-1}$ ),

95 high probiotic dose (continuous feeding of the basal diet supplemented with AquaStar ${ }^{\circledR}$

96 Growout at $3 \mathrm{~g} \mathrm{~kg}^{-1}$ ), probiotic pulse feeding (alternating weekly between AquaStar ${ }^{\circledR}$

97 Growout feeding at $1.5 \mathrm{~g} \mathrm{~kg}^{-1}$ and control feeding) and lastly initial probiotic feeding (first

98 two weeks AquaStar ${ }^{\circledR}$ Growout feeding at $1.5 \mathrm{~g} \mathrm{~kg}^{-1}$ followed by remainder of the trial on the

99 control diet). Diet codes were assigned for ease of analysis (Table 2). Fish were fed 100 experimental diets for six weeks at a rate of 1- 5\% biomass per day in four equal rations (all

101 treatments received the same \% input each day); higher feeding rates were provided at the

102 beginning of the trial but this was decreased incrementally during the trial as fish grew larger

103 and their appetite decreased. Daily feed was adjusted on a weekly basis by batch weighing

104 following a 24 hour starvation period. Fish were held at $28 \pm 1{ }^{\circ} \mathrm{C}$ with a $12: 12 \mathrm{~h}$ light: dark

105 photoperiod. Water quality was monitored daily and maintained at $\mathrm{pH}=6.5 \pm 0.5$ (adjusted

106 with $\mathrm{NaHCO}_{3}$ as necessary) and dissolved oxygen $>6.0 \mathrm{mg} \mathrm{l^{-1 }}$. Ammonium, nitrite and

107 nitrate levels were monitored weekly $\left(0.08 \pm 0.02,0.15 \pm 0.05\right.$ and $18.30 \pm 3.30 \mathrm{mg} \mathrm{l}^{-1}$,

108 respectively) and regular water changes prevented the accumulation of these compounds as

109 well as preventing background build-up of probiotics.

\section{$1112.2 \quad$ Growth performance and carcass composition}

112 Growth performance and feed utilisation were assessed by net weight gain (NWG), feed

113 intake (FI), specific growth rate (SGR), feed conversion ratio (FCR) and protein efficiency

114 ratio (PER). Calculations were carried out using the following formulae: NWG = FW - IW;

$115 \mathrm{SGR}=100((\ln \mathrm{FW}-\ln \mathrm{IW}) / \mathrm{T}) ; \mathrm{FCR}=\mathrm{FI} / \mathrm{WG} ; \mathrm{PER}=\mathrm{WG} / \mathrm{PI}$, where FW = final weight $(\mathrm{g})$,

116 IW = initial weight $(\mathrm{g}), \mathrm{T}=$ duration of feeding (days), $\mathrm{WG}=$ wet weight gain $(\mathrm{g}), \mathrm{FI}=$ feed

117 intake $(\mathrm{g})$ and $\mathrm{PI}=$ protein ingested $(\mathrm{g})$. At the end of the trial four fish per tank were pooled 
118 into two samples (thus $n=4$ ) to determine final carcass composition. Proximate composition

119 analysis was conducted according to AOAC protocols [21].

120

121

\section{$2.3 \quad R T-P C R$}

122 The mid-intestine was sampled from four fish per tank $(n=8)$ for gene expression of caspase-

123 3, PCNA, HSP70, TLR2, TGF $\beta$, IL-10, TNF $\alpha$ and IL-1 $\beta$ after six weeks. Total RNA was

124 extracted using TRIzol (Invitrogen) according to the manufacturer's protocol as described in

125 Rawling et al. [22] with the addition of an extra isopropanol step. RNA concentration and purity was measured spectophotometrically (NanoDrop Technologies) and RNA integrity was checked by running each sample on a $1 \%$ agarose gel. Any samples with DNA contamination were cleaned using RNeasy MiniElute Cleanup Kit (Qiagen). RNA samples were subsequently stored at $-80^{\circ} \mathrm{C}$ until use.

A total concentration of $1 \mu \mathrm{g}$ of RNA was used for cDNA synthesis using iScript cDNA Synthesis Kit (BioRad) according to manufacturer's instructions. Primer efficiencies were

132 determined using serial $1 / 10$ dilutions of pooled cDNA and resulting plots of $\mathrm{Ct}$ versus the 133 logarithmic cDNA input, using the equation $\mathrm{E}=10\left(^{-1 / \text { slope }}\right)$. Primer sequences and efficiencies are reported in Table 3. PCR reactions were run in duplicate (total reaction volume $=7.5 \mu \mathrm{l}$ ) were set on a 384-well plate and each reaction consisted of $2 \mu \mathrm{l}$ of cDNA (1/10 dilution), $3.75 \mu 1$ of $2 X$ concentrated SYBR Green Supermix (Biorad), $0.225 \mu 1$ of each forward and 137 reverse primers $(0.3 \mu \mathrm{M})$ and $1.3 \mu \mathrm{l}$ of DEPC treated water (Ambion). All quality control 138 measures and RT-reactions were carried out according to the MIQE guidelines [23]. The thermal profile for all reactions were $10 \mathrm{~min}$ at $95^{\circ} \mathrm{C}$ and then 40 cycles of $15 \mathrm{~s}$ at $95^{\circ} \mathrm{C}$ and analyses were performed in all cases to check for a single peak. GAPDH, $\beta$-actin and EF1- $\alpha$ 
142 were all assessed as reference genes. Reference genes were imported into GeNorm (v 3.4,

143 Center for Medical Research, Ghent University, Belgium) to assess the optimal number, and

144 choices of reference genes. Experimental treatments were each compared to the control and 145 analysed using the relative expression software tool $\left(\operatorname{REST}^{\odot}\right)$ [24] and reported as fold 146 change.

\section{$2.4 \quad$ Intestinal histology}

149 Four tilapia per tank were sampled at week six $(n=8)$ for histological appraisal of the mid150 intestine. Tissue samples were fixed in $10 \%$ formalin and transferred to $70 \%$ ethanol after 48 151 hours. Samples were then dehydrated in graded ethanol concentrations prior to embedding in 152 paraffin wax. In each specimen, multiple sections $(5 \mu \mathrm{m})$ were stained with haematoxylin and $153 \operatorname{eosin}(\mathrm{H} \& \mathrm{E})$ and Alcian Blue-PAS to assess the intestinal perimeter ratio (arbitrary units; 154 AU) after Dimitroglou et al. [25], intraepithelial leucocytes (IEL's) levels and goblet cell 155 abundance in the epithelium. IEL's and goblet cells were counted across a standardized distance of $100 \mu \mathrm{m}$ and then calculated by averaging the cell numbers from all samples within each treatment. All light microscopy images were analysed with Image J 1.46r 158 (National Institute of Health, USA).

\subsection{Intestinal microbiological analyses}

161 After the experimental period, four fish per tank were euthanized by overdose $\left(300 \mathrm{mg}^{-1}\right)$ of 162 tricaine methane sulphonate (MS222; Pharmaq, Fordingbridge, UK). The GI tract was 163 aseptically removed in its entirety. Faecal matter from the mid-intestine was isolated, and 164 pooled between two fish (thus $n=4$ per treatment) to assess allochthonous bacterial 
165

166

167

168

169

170

171

172

173

174

175

176

177

178

179

180

181

182

183

184

185

186

populations. Intestinal samples were either used immediately for culture based analysis or stored at $-20^{\circ} \mathrm{C}$ for culture independent analysis.

\subsubsection{Culture dependent analysis}

Samples were serially diluted with PBS and $20 \mu 1$ was spotted onto duplicate MRS agar, Slanetz and Bartley and Bacillus selective media using the Miles and Misra method [26] to assess the allochthonous presumptive probiotic bacterial populations. Tryptone soya agar (TSA) was used to determine the total aerobic heterotrophic bacterial populations. Plates were incubated for 48 hours at $28^{\circ} \mathrm{C}$ and colony forming units $\left(\mathrm{CFU} \mathrm{g} \mathrm{g}^{-1}\right)$ were calculated by counting colonies from statistically viable plates (between 3-30 colonies). Representative subsets of the presumptive probiotics were identified by using 16S rRNA gene sequence analysis using the protocol described in Ferguson et al. [27].

\subsubsection{Culture independent analysis}

At week six, digesta samples $(n=4)$ were used for culture independent analyses. DNA was extracted using the QIAamp Stool Mini Kit (Qiagen) with a lysozyme pre-treatment (50 mg $\mathrm{mL}^{-1}$ in TE buffer for $30 \mathrm{~min}$ at $37^{\circ} \mathrm{C}$ ) and a phenol-chloroform clean up, as described [28].

PCR amplification of the $16 \mathrm{~S}$ rRNA V3 region was conducted using the reverse primer P2 and the forward primer P3 [29]. A 40-60\% DGGE was performed, and presumptive probiotic bands extracted, using a DCode Universal Mutation Detection System (Bio-Rad laboratories, Italy) according to Merrifield et al [30]. The presumptive probiotic nucleotide sequences were submitted to a BLAST search to retrieve the closest known alignment identities. 


\subsection{Statistical analyses}

189 All data are presented as means \pm standard deviation. All data were checked for normality 190 and analysed using ANOVA with post-hoc Tukey's HSD test (Statgraphics Centurion XVI, 191 Warrenton, VA, USA). Where data were not normally distributed, data were analysed using a 192 Kruskal- Wallis test with post-hoc Mann-Whitney U-tests. RT-PCR data were analysed using 193 REST $^{\odot} 2009$ (Qiagen, Hilden, Germany). DGGE banding patterns were transformed into 194 presence/ absence matrices based on band peak intensities (Quantity One ${ }^{\circledR}$ version 4.6.3, Bio195 Rad Laboratories, CA, USA). Band intensities were measured (Quantity One ${ }^{\circledR}$ 1-D Analysis 196 Software, Bio-Rad Laboratories Ltd., Hertfordshire, UK), and analysed using Primer V6 197 software (PRIMER-E Ltd, Ivybridge, UK). In all cases, significance was accepted at $P<0.05$.

$1993 \quad$ Results

\subsection{Growth performance and carcass composition}

201 Growth performance was assessed by means of routine growth and feed utilisation 202 parameters after six weeks of feeding experimental feeding (Table 4). Tilapia fed the PRO-3 diet displayed the best growth performance. In this treatment the final weight, weight gain and SGR were significantly higher when compared to either CON or PRO-INI $(P=0.019$, 0.014 and 0.021 , respectively). However, they did not significantly differ from treatments PRO-1.5 or PRO-PULSE. No differences in feed intake, PER or FCR were observed between any treatment $(P=0.054,0.190$ and 0.237 , respectively). Additionally, there were no significant differences in carcass proximal composition (Table 4). 
212 Relative intestinal gene expression of caspase-3, PCNA, HSP70, TLR2, TNF $\alpha$, IL-1 $\beta$, IL-10

213 and TGF $\beta$ were analysed. The largest fold change was observed in caspase- 3 mRNA levels

214 which were up-regulated approximately seven fold in PRO-3 when compared to the control

215 group $(P=0.001)$. The gene expression of PCNA and HSP70 were six and three and half

216 times higher in PRO-3, respectively, when compared to the control treatment $(P<0.001$ and

2170.028 respectively; Figure 1).

218 Further changes were observed for the immunity related genes (Figure 2). TLR2 mRNA 219 expression was significantly up-regulated, more than four fold, in PRO-3 when compared to 220 the control treatment $(P=0.004)$. The pro-inflammatory cytokine genes TNF $\alpha$ and IL-1 $\beta$ were up-regulated three and five times, respectively, in the intestine of the PRO-3 fed fish compared to the $\mathrm{CON}$ fed fish $(P=0.028$ and 0.003 , respectively). Furthermore, tolerogenic cytokine IL-10 and TGF $\beta$ mRNA levels were also up-regulated by approximately five and six fold, respectively, in PRO-3 when compared to the control treatment $(P=0.005$ and 0.003 , respectively).

There were no significant changes in gene expression between any of the investigated genes between treatments PRO-1.5, PR0-PULSE and PRO-INI when compared to the control treatment $(P>0.05)$.

\subsection{Intestinal histology}

231 Light microscopy was used to examine the perimeter ratio, IEL and goblet cell levels from the mid-intestine (Table 5). Fish from all dietary treatments had an intact epithelial barrier 
234 treatments showed altered perimeter ratios $(P=0.007)$. The highest perimeter ratio was 235 recorded in PRO-INI which was significantly higher than PRO-1.5 but not CON, PRO-3 or 236 PRO-PULSE. Perimeter ratio in PRO-3 was also significantly higher when compared to the 237 lower probiotic dose, PRO-1.5. However, perimeter ratio remained unchanged between 238 treatments PRO-1.5, CON, and PRO-PULSE. IEL and goblet cell abundance remained unchanged by dietary treatment in groups CON, PRO-1.5, PRO-PULSE and PRO-INI.

240 However, IEL levels were significantly elevated in PRO-3 when compared to treatments 241 CON, PRO-PULSE and PRO-INI $(P<0.05)$ but not PRO-1.5. PRO-3 also contained 242 significantly larger populations of goblet cell when compared to all other treatments $(P<$ 243 0.001; Table 5).

\subsection{Culture dependent analysis}

246 The effect of AquaStar ${ }^{\circledR}$ Growout treatment on the aerobic heterotrophic bacteria was 247 determined using culture based methods (Table 6). No significant differences were observed 248 in TVC levels between the treatments with allochthonous levels approximately $\log 6 \mathrm{CFU} \mathrm{g}^{-1}$ 249 for each treatment $(P=0.993)$. The highest LAB levels were observed in the digesta of PRO2503 fed tilapia, these were significantly higher than of CON and PRO-INI $(P=0.006)$. 251 Similarly, PRO-3 resulted in the highest Bacillus levels which were significantly higher than 252 those found in PRO-PULSE but not in other treatments $(P=0.026)$. LAB and Bacillus populations were not different in treatments CON, PRO-1.5, PRO-PULSE and PRO-INI. Furthermore, enterococci levels were significantly higher in PRO-3 when compared to CON, PRO-PULSE and PRO-INI. Despite being numerically higher, they were not different to enterococci levels recovered in PRO-1.5 digesta. Representative subsets of the presumptive probiotics were confirmed as the probiotics by $16 \mathrm{~S}$ rRNA gene sequence analysis. 
259 The influence of dietary AquaStar ${ }^{\circledR}$ Growout on the intestinal microbial diversity in tilapia was investigated using DGGE after six weeks of feeding experimental diets. Presumptive probiotic bands were identified by migration to the same position as known B. subtilis, E.

262 faecium, L. reuteri and P. acidilactici samples. These bands were also isolated from DGGE

263 gels and subsequent sequencing confirmed the presence of all four probiotic species from 264 AquaStar $^{\circledR}$ Growout fingerprints; these were not detected in control sample fingerprints. 265 Table 7 displays the microbial ecological parameters derived from the DGGE fingerprints. There were no significant differences between treatments with regards to number of OTU's $(N)$, species richness or diversity indices $(P=0.083,0.086$ and 0.102 , respectively). Replicates from CON and PRO-PULSE showed the highest similarity percentage (SIMPER), this was significantly higher than replicates in PRO-1.5 but not those in PRO-3 or PRO-INI. Apart from PRO-1.5, all other treatments displayed no differences with regards to SIMPER analyses. ANOSIM revealed that the microbial communities within PRO-3 fed tilapia were 272 significantly dissimilar to CON, PRO-PULSE and PRO-INI $(53.35 \%, 58.25 \%$ and 58.10\% 273 dissimilar, respectively; $P=0.03$ ) but not PRO-1.5 (34.54\% dissimilar; $P=0.23$ ). 274 Additionally, the microbial community within PRO-1.5 was significantly dissimilar to the 275 microbial community within the intestine of PRO-PULSE $(40.33 \%$ dissimilar; $P=0.03)$. This can be visualised in Figure 3 where there is a clustering effect of the communities from 277 the PRO-3 replicates. Replicates from treatments CON, PRO-PULSE and PRO-INI showed 278 loose clustering with level of overlap between these three treatments. Two out of four 279 replicates from PRO-1.5 show high similarity to those from PRO-3, whereas the remaining two replicates are more similar to the other treatments (Figure 3). 
284 The administration of AquaStar ${ }^{\circledR}$ Growout at $3 \mathrm{~g} \mathrm{~kg}^{-1}$ for six weeks resulted in improved

285 growth performance when compared to treatments CON or PRO-INI. AquaStar ${ }^{\circledR}$ Hatchery

286 (which contains a higher concentration of the same probiotic strains as AquaStar ${ }^{\circledR}$ Growout) $^{-1}$

287 has previously been reported to improve growth performance of rainbow trout

288 (Oncorhynchus mykiss) [31]. Although there is no data regarding the growth promoting

289 effects of AquaStar ${ }^{\circledR}$ Growout in tilapia, dietary provision of Bacillus spp., Enterococcus spp.

290 and Lactobacillus spp., either singularly or in combination with other species have been

291 reported to improve tilapia growth performance indicators [2, 4-8, 32-35]. The mechanisms

292 which underpin these improvements are only partly described. Previous work on tilapia

293 suggests that Aquastar ${ }^{\circledR}$ Growout may increase the intestinal absorptive surface area by

294 improving the microvilli density and microvilli length [36]. Probiotics may also be important

295 in the production of digestive enzymes. Essa et al. [6] reported elevated intestinal amylase,

296 protease and lipase activities in tilapia supplemented with B. subtilis and/ or L. rhamnosus

297 and elevated intestinal protease activity in fish supplemented with $S$. cerevisae.

298 Heat shock proteins have important roles in protein metabolism, protein folding, protein 299 chaperoning, mediating the repair and degradation of damaged proteins and are also involved in generating an immune response [38]. Furthermore it has also been proposed that heat shock proteins play important roles in the long term adaptation of animals to their

302 environments through genetic mechanisms [39]. Fish exhibiting higher HSP70 expression

303 may therefore be more able to generate an efficient immune response and also be more tolerant to a wider range of environmental conditions. In the present study gene expression analyses were used to elucidate the effect of the probiotic treatment on the mid-intestine at the molecular level. Many authors have reported lower expression of HSP70 after probiotic administration in fish [40-42] including tilapia [11]. Here, intestinal HSP70 gene expression 
308 showed the opposite trend as it was significantly higher in PRO-3 when compared to the 309 control. Using an ex vivo approach, Ren et al. [13] demonstrated that exposure to Aeromonas 310 hydrophila did not cause an upregulation of HSP70 in the anterior or posterior intestine of 311 tilapia. Conversely, the addition of Lactobacillus plantarum, as well as a mix of $A$.

312 hydrophila and L. plantarum to the intestinal sac caused an upregulation of HSP70 [13].

313 Similar results were reported by Liu et al. [12] after the feeding hybrid tilapia, O. niloticus x 314 Oreochromis aureus, diets supplemented with two Lactobacillus species. From their studies

315 it was also evident that there appears to be a dosage, as well as temporal effect. For example,

316 after 10 days of feeding on the probiotic diet, intestinal HSP70 was significantly up-regulated,

317 down-regulated after 20 days and not different after 35 days when compared to the control

318 treatment.

319 Caspase-3 and PCNA gene expression were both significantly up-regulated in PRO-3 when 320 compared with the control group. Caspase-3 is part of the cysteine-aspartic acid protease 321 family where it is activated by initiator caspases- 8 or 9 resulting in programmed cell death 322 (apoptosis). On the other hand, PCNA (proliferating cell nuclear antigen) is a marker for cell proliferation and is crucial for cellular and DNA replication. Organised apoptosis is essential

324 for the health of the host since it results in the elimination of dangerous or damaged cells

325 without causing an inflammatory response or tissue damage [43]. Since the GI tract is one of 326 the key sites of interaction with the external environment [44] the intestine could be exposed to a number of opportunistic pathogens or chemical contaminants, especially in aquaculture where high stocking densities and water quality can be problematic. Therefore, both an elevated proliferative and apoptotic capacity is likely to be beneficial to the host.

The gut associated lymphoid tissue (GALT) in fish differs from their mammalian counterparts since fish lack Peyer's patches and mesenteric lymph nodes. Teleosts possess a more diffusely organised GALT which provides a physical, chemical and cellular barrier to 
pathogenic invasion [9]. Similar to mammalian models, immune and epithelial cells within the GALT of fish express pattern recognition receptors (PRR's) including toll-like receptors (TLR's), which are sensitive to a number of pathogen associated molecular patterns (PAMP's). Upon ligation, a cascade effect is initiated through a series of adaptor proteins and transcription factors resulting in the transcription of important immune molecules such as cytokines, chemokines and defensins [9].

TLR2 gene expression was up-regulated in PRO-3 when compared with the control treatment.

TLR2 is ligated by lipoteichoic acid (LTA), which is a major constituent in the cell wall of

341 Gram-positive bacteria [45], such as those present in AquaStar ${ }^{\circledR}$ Growout. This up-regulation,

342 induced by Gram-positive probiotics might be of particular importance because tilapia are 343 susceptible to a number of Gram-positive infections, in particular Streptococcus iniae and

344 Streptococcus agalactiae. Indeed, TLR2 was up-regulated in Mrigal carp (Cirrhinus mrigala)

345 following Streptococcus uberis infection as well as A. hydrophila infection [46], another 346 destructive pathogen in tilapia culture. It has been demonstrated that TLR's may have 347 important roles to play in the probiotic modulation of the innate immune system in other fish 348 species [17, 18]. Sun et al. [18] reported an upregulation in both TLR2 and TLR5 in grouper 349 (Epinephelus coioides) after Psychrobacter sp. supplementation. Furthermore, the authors 350 demonstrated a higher expression of pro-inflammatory genes IL-1 $\beta$ and IL-8, and the anti351 inflammatory gene TGF $\beta$ after probiotic supplementation. The present study also reports higher gene expression of both pro-inflammatory cytokines (TNF $\alpha$ and IL-1 $\beta$ ) and antiinflammatory cytokines (IL-10 and TGF $\beta$ ) after probiotic administration at $3 \mathrm{~g} \mathrm{~kg}^{-1}$ when compared to the control treatment. Here, despite the up-regulation of pro-inflammatory cytokines, there was no evidence of inflammation from histology examinations. It is possible that this was balanced by the up-regulation of anti-inflammatory cytokine gene expressions. 
358 probiotic feeding [10-15]. It is postulated that the induction of pro-inflammatory cytokines

359 improves immune readiness of the host. In support of this, disease resistance studies in tilapia

360 have demonstrated that probiotics are able to increase the expression of TNF $\alpha$ and IL-1 $\beta$ and

361 consequently the tilapia survival levels were significantly higher when exposed to $A$.

362 hydrophila $[12,15]$.

363 The current study also demonstrated that the probiotics also have anti-inflammatory

364 signalling effects, by inducing the up-regulation of TGF $\beta$ and IL-10. Naturally, anti-

365 inflammatory cytokines will have an immune-suppressive effect on the host; this could be

366 indicative of a tolerance mechanism where the host does not interpret the probiotic as a threat.

367 This has been demonstrated in other fish studies where TGF $\beta$ was up-regulated after

368 probiotic administration $[11,12]$. To the authors knowledge this is the first study to

369 demonstrate probiotic modulation of IL-10 in the intestine of tilapia after probiotic feeding.

370 However, similar results have been reported in rainbow trout after L. plantarum 371 supplementation [47].

372 Histological analyses revealed significantly larger populations of IEL's in the mid-intestine 373 of tilapia in PRO-3 when compared to treatments CON, PRO-PULSE or PRO-INI. Similar results have been obtained in other studies using tilapia fed diets supplemented with either $P$. acidilactici or Lactobacillus rhamnosus for six weeks and 30 days, respectively [10, 14]. Probiotic administration has led to increased IEL abundance in other commercially important

377 fish species including European sea bass (Dicentrarchus labrax) and gilthead sea bream 378 (Sparus aurata) [48, 49]. Whilst the type of IEL cannot be eluded to in this study, Picchietti et al. [49] characterised elevated T-cells and acidophilic granulocytes in the posterior intestine of European sea bass. These data suggest that probiotics not only act upon the innate immune system in fish, but may have important roles to play through adaptive immunity mechanisms too. 
383 Whilst all fish displayed abundant goblet cells within the intestine, there were significantly

384 larger populations in the mid-intestine of tilapia fed PRO-3 when compared to all other

385 treatments. Intestinal mucus is vital to the defensive barrier, both physically and chemically,

386 since it functions to trap and remove pathogens, preventing their attachment to the epithelia.

387 Dietary applications of L. rhamnosus and P. acidilactici have also been reported to increase

388 the number of goblet cells in the tilapia intestine $[14,50]$.

389 This study was successful in recovering each probiotic species from tilapia digesta, a

390 requirement which is essential for any probiotic candidate. Furthermore, probiotic supplementation was capable of modulating the composition of intestinal microbiota. This supports a previous study which also reported the detection of these probiotic species, and modulation of the intestinal microbiota, of tilapia using DGGE and high-throughput sequencing [36].

395 In conclusion, under the current experimental conditions, the continuous supplementation of 396 AquaStar $^{\circledR}$ Growout at $3 \mathrm{~g} \mathrm{~kg}^{-1}$ can improve growth performance and elevate the intestinal 397 immunological status in tilapia. The probiotic may act to augment mucosal tolerance 398 mechanisms whilst creating a state of immune readiness, improved barrier function through the increase the number of goblet cells and IELs in the intestine, which may ultimately retard pathogen infection and translocation. Future studies should assess these using challenge trials.

\section{Conflict of interest}

403 The authors declare that there are no conflicts of interest that could have direct or potential 404 influence or impart bias on the work. 
407 This work was carried out as part of a $\mathrm{PhD}$ studentship which was jointly funded by 408 Plymouth University and Biomin GmbH (Herzogenburg, Austria). The authors would like to 409 thank Biomin GmbH for providing the materials for this research as well as their input with 410 regards to experimental design. Finally, the authors would like to thank all colleagues for 411 their assistance in the laboratory specifically Ben Eynon for his experience in fish husbandry 412 and Matthew Emery and Dr Ana Rodiles for their microbiological assistance.

414 Figure 1: Relative mid-intestinal gene expression of caspase-3 and PCNA and HSP70 after 415 six weeks of feeding experimental diets. Values are reported in fold change when compared 416 against the expression in the control treatment (set to 1.0). Asterisks highlight significant 417 differences $(P<0.05)$ when compared to the control treatment.

419 Figure 2: Relative gene expression of mid-intestinal TLR2 receptor (A) pro-inflammatory cytokines TNF $\alpha$ (B) and IL-1 $\beta$ (C) and anti-inflammatory cytokines TGF $\beta$ (D) and IL-10 (E) and after six weeks of feeding experimental diets. Values are reported in fold change when compared against the expression in the control treatment (set to 1.0). Asterisks highlight significant differences $(P<0.05)$ when compared to the control treatment.

425 Figure 3: nMDS plot showing similarity of the intestinal allochthonous microbiota of each treatment after six weeks of feeding experimental diets. Lines represent different levels of similarity. 
Table 1: Dietary formulation and chemical composition (\%).

\begin{tabular}{lccc}
\hline & Basal & $1.5 \mathrm{~g} \mathrm{~kg}^{-1}$ & $3 \mathrm{~g} \mathrm{~kg}^{-1}$ \\
\hline Fishmeal $^{\mathrm{a}}$ & 10.00 & 10.00 & 10.00 \\
Soyabean meal $^{\mathrm{b}}$ & 33.89 & 33.89 & 33.89 \\
Corn Starch $^{\mathrm{c}}$ & 31.90 & 31.75 & 31.60 \\
Lysamine pea protein $^{\mathrm{d}}$ & 5.00 & 5.00 & 5.00 \\
Glutalys $^{\mathrm{d}}$ & 10.00 & 10.00 & 10.00 \\
Fish oil $_{\text {Corn oil }}$ & 3.75 & 3.75 & 3.75 \\
Vitamin\& mineral premix $^{\mathrm{f}}$ & 4.00 & 4.00 & 4.00 \\
CMC-binder $^{\mathrm{c}}$ & 0.50 & 0.50 & 0.50 \\
Methionine $^{\mathrm{c}}$ & 0.50 & 0.50 & 0.50 \\
AquaStar $^{\circledR}$ Growout $^{\mathrm{g}}$ & 0.36 & 0.36 & 0.36 \\
\end{tabular}

Proximate composition (\% as fed basis)

\begin{tabular}{lccc}
\hline Moisture & $7.16 \pm 0.03$ & $5.89 \pm 0.09$ & $8.23 \pm 0.19$ \\
Crude protein & $37.57 \pm 0.16$ & $38.08 \pm 0.30$ & $37.03 \pm 0.13$ \\
Lipid & $10.09 \pm 0.03$ & $10.61 \pm 0.24$ & $10.41 \pm 0.09$ \\
Ash & $4.29 \pm 0.04$ & $4.25 \pm 0.07$ & $4.20 \pm 0.01$ \\
Energy $\left(\mathrm{MJ} \mathrm{kg}^{-1}\right)$ & $19.72 \pm 0.05$ & $19.57 \pm 0.40$ & $18.97 \pm 0.19$
\end{tabular}

${ }^{a}$ Herring meal LT92 - United Fish Products Ltd., Aberdeen, UK.

$430{ }^{\mathrm{b}}$ Hamlet HP100, Denmark.

$431{ }^{\mathrm{c}}$ Sigma- Aldrich Ltd., UK.

$432{ }^{\mathrm{d}}$ Roquette Frêres, France.

$433{ }^{\mathrm{e}}$ Natural wheat bran, Holland \& Barrett, UK.

$434{ }^{\mathrm{f}}$ Premier nutrition vitamin/mineral premix contains: $121 \mathrm{~g} \mathrm{~kg}^{-1}$ calcium, Vit A $1.0 \mu \mathrm{g} \mathrm{kg}^{-1}$,

435 Vit D3 $0.1 \mu \mathrm{g} \mathrm{kg}^{-1}$, Vit E (as alpha tocopherol acetate) $7.0 \mathrm{~g} \mathrm{~kg}^{-1}$, Copper (as cupric sulphate)

$436250 \mathrm{mg} \mathrm{kg}^{-1}$, Magnesium $15.6 \mathrm{~g} \mathrm{~kg}^{-1}$, Phosphorous $5.2 \mathrm{~g} \mathrm{~kg}^{-1}$.

$437 \quad \mathrm{~g}$ Biomin Holding GmbH, Industriestrasse 21, 3130 Herzogenburg, Austria.

438

439

440

441 
444 Table 2: Dietary codes used throughout the research article.

\begin{tabular}{ll}
\hline Dietary code & Diet \\
\hline CON & Continuous feeding of basal diet (without probiotic) \\
PRO-1.5 & Continuous feeding of the basal diet supplemented with AquaStar \\
& Growout at $1.5 \mathrm{~g} \mathrm{~kg}^{-1}$ \\
PRO-3 & Continuous feeding of the basal diet supplemented with AquaStar \\
& Growout at $3 \mathrm{~g} \mathrm{~kg}^{\circledR}$ \\
PRO-PULSE & Alternating weekly between AquaStar ${ }^{\circledR}$ Growout feeding at $1.5 \mathrm{~g} \mathrm{~kg}^{-1}$ \\
& and the basal diet \\
PRO-INI & Initial two weeks AquaStar ${ }^{\circledR}$ Growout feeding at $1.5 \mathrm{~g} \mathrm{~kg}^{-1}$ followed by \\
& remainder of the trial on the basal diet \\
\hline
\end{tabular}


Table 3: Primer sequences used for RT-PCR

\begin{tabular}{|c|c|c|c|c|c|c|}
\hline Gene & Forward 5' - 3' & Reverse 5' - 3' & $\begin{array}{c}\text { Amplicon } \\
\text { size }\end{array}$ & $\begin{array}{l}\mathrm{Tm} \\
\left({ }^{\circ} \mathrm{C}\right)\end{array}$ & $\begin{array}{c}\text { E- } \\
\text { value }\end{array}$ & GenBank number \\
\hline$\beta$-actin & TGACCTCACAGACTACCTCATG & TGATGTCACGCACGATTTCC & 89 & 58.8 & 2.1 & KJ126772.1 \\
\hline $\mathrm{EF} 1 \alpha$ & TGATCTACAAGTGCGGAGGAA & GGAGCCCTTTCCCATCTCA & 80 & 58.4 & 2.0 & $\mathrm{AB} 075952.1$ \\
\hline PCNA & CCCTGGTGGTGGAGTACAAG & AGAAGCCTCCTCATCGATCTTC & 80 & 60.9 & 2.0 & XM_003451046.2 \\
\hline HSP70 & ACCCAGACCTTCACCACCTA & GTCCTTGGTCATGGCTCTCT & 84 & 59.4 & 2.0 & FJ213839.1 \\
\hline TLR2 & GCAGTGCCTTGAGTCTTGATC & ACCGTGGAGATCGAGAACCT & 101 & 59.6 & 2.1 & XM_005460165 \\
\hline IL-10 & CTGCTAGATCAGTCCGTCGAA & GCAGAACCGTGTCCAGGTAA & 94 & 59.6 & 2.1 & XM_003441366.2 \\
\hline
\end{tabular}


448 Table 4: Growth performance and final carcass composition of tilapia after six weeks of feeding on experimental diets.

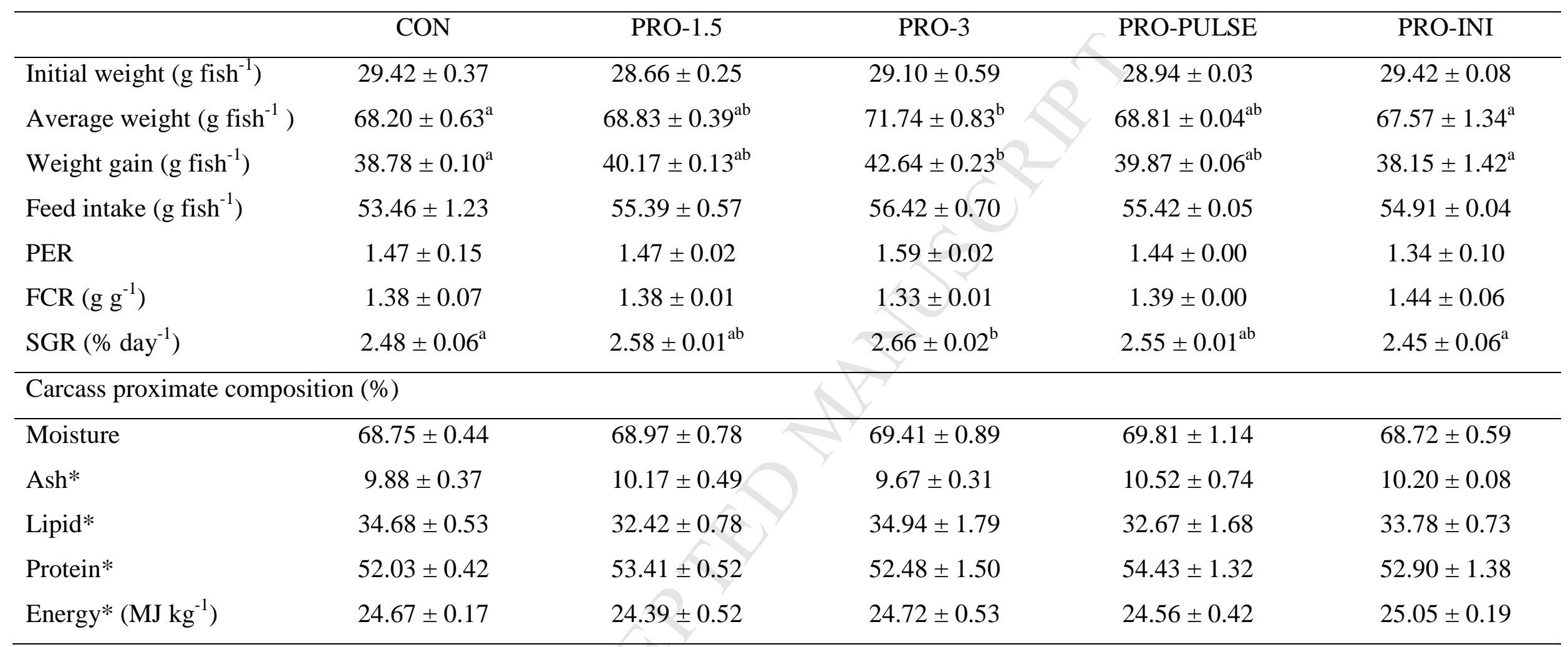

$449 *$ Parameters reported as percentage of dry weight matter.

$450 \quad{ }^{\mathrm{a}, \mathrm{b}}$ Different superscripts indicate a significant difference $(P<0.05)$. 
Table 5: Histological data from the mid-intestine of tilapia fed control and AquaStar ${ }^{\circledR}$ Growout supplemented diets after six weeks of feeding on experimental diets.

\begin{tabular}{|c|c|c|c|c|c|}
\hline & $\mathrm{CON}$ & PRO-1.5 & PRO-3 & PRO-PULSE & PRO-INI \\
\hline Perimeter ratio (AU) & $2.57 \pm 0.58^{\mathrm{ab}}$ & $2.03 \pm 0.29^{\mathrm{a}}$ & $3.16 \pm 0.86^{b}$ & $2.94 \pm 0.47^{\mathrm{ab}}$ & $3.68 \pm 0.72^{b}$ \\
\hline IEL's (per $100 \mu \mathrm{m})$ & $34.04 \pm 4.41^{\mathrm{a}}$ & $37.39 \pm 3.60^{\mathrm{ab}}$ & $41.63 \pm 2.66^{\mathrm{b}}$ & $34.85 \pm 2.99^{\mathrm{a}}$ & $31.95 \pm 1.61^{\mathrm{a}}$ \\
\hline Goblet cells (per $100 \mu \mathrm{m}$ ) & $4.96 \pm 1.53^{\mathrm{a}}$ & $4.95 \pm 0.91^{\mathrm{a}}$ & $8.56 \pm 0.82^{b}$ & $5.18 \pm 0.64^{\mathrm{a}}$ & $5.58 \pm 1.33^{\mathrm{a}}$ \\
\hline
\end{tabular}

${ }^{\mathrm{a}, \mathrm{b}}$ Different superscripts indicate a significant difference $(P<0.05)$. 
461 Table 6: Allochthonous TVC, LAB, enterococci and Bacillus spp. (log CFU g $\mathrm{g}^{-1}$ ) in the 462 intestinal tract of tilapia after six weeks of feeding on experimental diets.

\begin{tabular}{lccccc}
\hline & CON & PRO-1.5 & PRO-3 & PRO-PULSE & PRO-INI \\
\hline TVC & $5.89 \pm 0.59$ & $5.92 \pm 0.27$ & $5.94 \pm 0.28$ & $6.01 \pm 0.53$ & $6.05 \pm 0.51$ \\
LAB & $1.08 \pm 1.34^{\mathrm{a}}$ & $3.30 \pm 1.86^{\mathrm{ab}}$ & $5.39 \pm 0.83^{\mathrm{b}}$ & $2.45 \pm 2.18^{\mathrm{ab}}$ & $\mathrm{n} . \mathrm{d}^{\mathrm{a}}$ \\
Bacillus spp. & $4.30 \pm 0.25^{\mathrm{ab}}$ & $4.57 \pm 0.22^{\mathrm{ab}}$ & $5.18 \pm 0.58^{\mathrm{b}}$ & $3.87 \pm 0.43^{\mathrm{a}}$ & $4.10 \pm 0.45^{\mathrm{ab}}$ \\
Enterococci & $\mathrm{n} . \mathrm{d}^{\mathrm{a}}$ & $3.13 \pm 1.72^{\mathrm{bc}}$ & $5.03 \pm 0.99^{\mathrm{c}}$ & $0.94 \pm 1.12^{\mathrm{ab}}$ & $\mathrm{n} . \mathrm{d}^{\mathrm{a}}$ \\
\hline
\end{tabular}


Table 7: Microbial community analysis of the intestinal allochthonous bacterial populations of tilapia from DGGE fingerprints after six weeks of feeding on experimental diets.

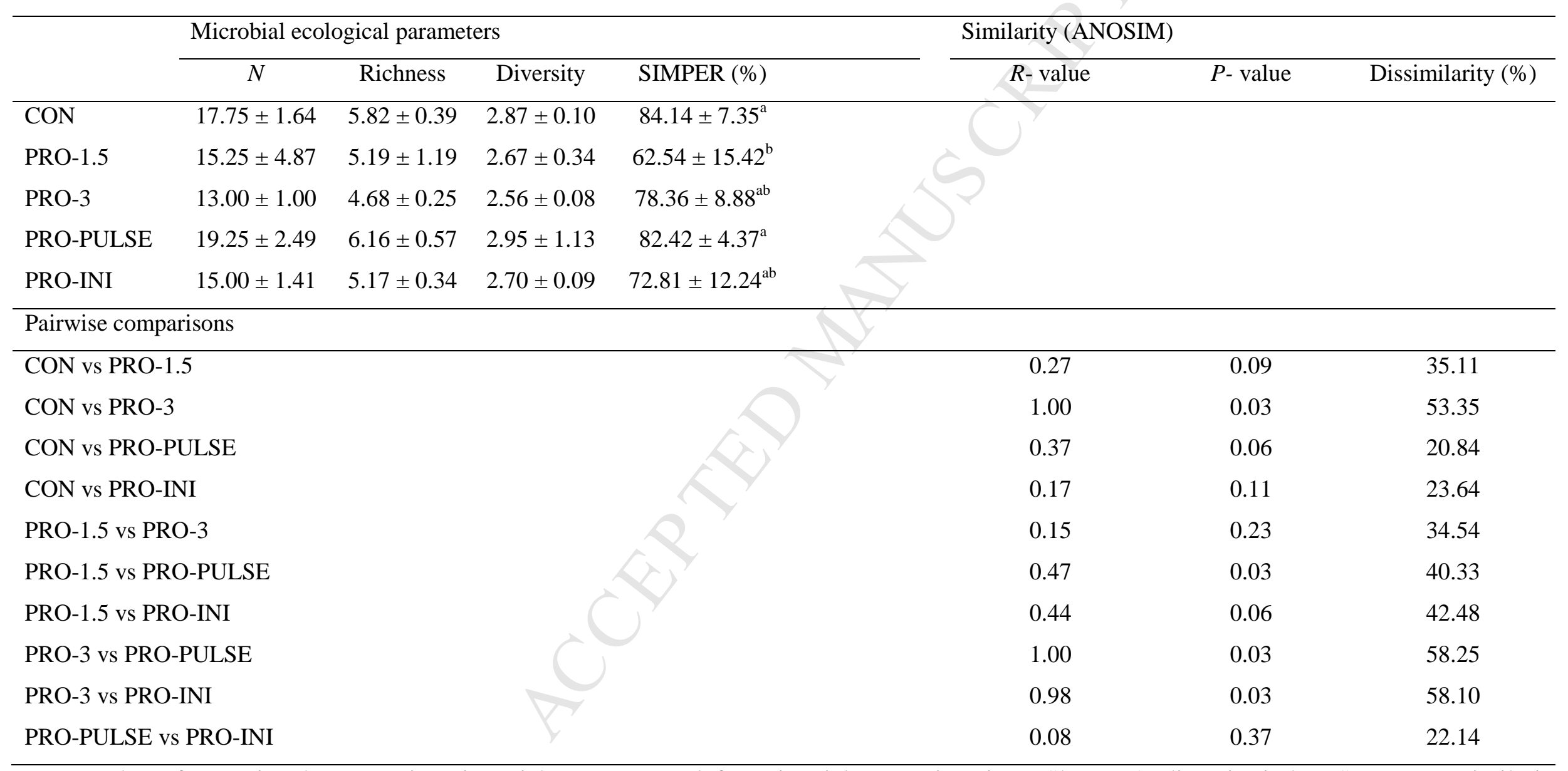

$N=$ number of operational taxonomic units; Richness = Margalef species richness; Diversity = Shannon's diversity index; SIMPER = similarity percentage within group replicates.

a, b Different superscripts indicate a significant difference $(P<0.05)$. 
References

1. FAO. The State of World Fisheries and Aquaculture 2014. Food Agricultural Organization United Nations.; 2014.

2. El-Haroun ER, Goda AMAS, Kabir Chowdhury MA. Effect of dietary probiotic Biogen ${ }^{\circledR}$ supplementation as a growth promoter on growth performance and feed utilization of Nile tilapia Oreochromis niloticus (L.). Aquac Res. 2006 37:1473-80.

3. Abdel-Tawwab M, Abdel-Rahman AM, Ismael NEM. Evaluation of commercial live bakers' yeast, Saccharomyces cerevisiae as a growth and immunity promoter for Fry Nile tilapia, Oreochromis niloticus (L.) challenged in situ with Aeromonas hydrophila. Aquaculture. 2008 280:185-9.

4. Wang Y-B, Tian Z-Q, Yao J-T, Li W-f. Effect of probiotics, Enteroccus faecium, on tilapia (Oreochromis niloticus) growth performance and immune response. Aquaculture. 2008 277:203-7.

5. Apún-Molina JP, Santamaría- Miranda A, Luna-González A, Martínez-Díaz SF, Rojas-Contreras M. Effect of potential probiotic bacteria on growth and survival of tilapia Oreochromis niloticus L., cultured in the laboratory under high density and suboptimum temperature. Aquac Res. 2009 40:887-94.

6. Essa M, El-Serafy S, El-Ezabi M, Davboor S, Esmael N, Lall S. Effect of different dietary probiotics on growth, feed utilization and digestive enzymes activities of Nile tilapia, Oreochromis niloticus. J Arabian Aquac Soc. 2010 5:143-61.

7. Zhou X, Tian Z, Wang Y, Li W. Effect of treatment with probiotics as water additives on tilapia (Oreochromis niloticus) growth performance and immune response. Fish Physiol Biochem. 2010 36:501-9.

8. Ayyat MS, Labib HM, Mahmoud HK. A probiotic cocktail as a growth promoter in Nile tilapia (Oreochromis niloticus). J Appl Aquac. 2014 26:208-15. 
9. Foey A, Picchietti S. Immune defences of teleost fish. Chichester: John Wiley \& Sons Ltd; 2014.

10. Pirarat N, Pinpimai K, Endo M, Katagiri T, Ponpornpisit A, Chansue N, et al. Modulation of intestinal morphology and immunity in nile tilapia (Oreochromis niloticus) by Lactobacillus rhamnosus GG. Res Vet Sci. 2011 91:e92-e7.

11. He S, Zhang Y, Xu L, Yang Y, Marubashi T, Zhou Z, et al. Effects of dietary Bacillus subtilis $\mathrm{C}-3102$ on the production, intestinal cytokine expression and autochthonous bacteria of hybrid tilapia Oreochromis niloticus ○; Oreochromis aureus §ิ. Aquaculture. 2013 412413:125-30.

12. Liu W, Ren P, He S, Xu L, Yang Y, Gu Z, et al. Comparison of adhesive gut bacteria composition, immunity, and disease resistance in juvenile hybrid tilapia fed two different Lactobacillus strains. Fish Shellfish Immunol. 2013 35:54-62.

13. Ren P, Xu L, Yang Y, He S, Liu W, Ring $\varnothing$ E, et al. Lactobacillus plantarum subsp. plantarum JCM 1149 vs. Aeromonas hydrophila NJ-1 in the anterior intestine and posterior intestine of hybrid tilapia Oreochromis niloticus $q \times$ Oreochromis aureus ${ }^{\top}:$ An ex vivo study. Fish Shellfish Immunol. 2013 35:146-53.

14. Standen BT, Rawling MD, Davies SJ, Castex M, Foey A, Gioacchini G, et al. Probiotic Pediococcus acidilactici modulates both localised intestinal- and peripheralimmunity in tilapia (Oreochromis niloticus). Fish Shellfish Immunol. 2013 35:1097-104.

15. Villamil L, Reyes C, Martínez-Silva MA. In vivo and in vitro assessment of Lactobacillus acidophilus as probiotic for tilapia (Oreochromis niloticus, Perciformes:Cichlidae) culture improvement. Aquac Res. 2014 45:1116-25.

16. Cerf-Bensussan N, Gaboriau-Routhiau V. The immune system and the gut microbiota: friends or foes? Nat Rev Immunol. 2010 10:735-44. 
17. Abid A, Davies SJ, Waines P, Emery M, Castex M, Gioacchini G, et al. Dietary synbiotic application modulates Atlantic salmon (Salmo salar) intestinal microbial communities and intestinal immunity. Fish Shellfish Immunol. 2013 35:1948-56.

18. Sun Y-Z, Xia H-Q, Yang H-L, Wang Y-L, Zou W-C. TLR2 signaling may play a key role in the probiotic modulation of intestinal microbiota in grouper Epinephelus coioides. Aquaculture. 2014 430:50-6.

19. Merrifield DL, Dimitroglou A, Foey A, Davies SJ, Baker RTM, Bøgwald J, et al. The current status and future focus of probiotic and prebiotic applications for salmonids. Aquaculture. 2010 302:1-18.

20. NRC. Nutrient Requirements of Fish and Shrimp. Washington: The National Academies Press. 2011:376.

21. AOAC. Association Official Analytical Chemists (AOAC). (1995) Official Methods of Analysis. Association of Official Analytical Chemists. Arlington, VA; 1995.

22. Rawling MD, Merrifield DL, Kühlwein H, Snellgrove D, Gioacchini G, Carnevali O, et al. Dietary modulation of immune response and related gene expression profiles in mirror carp (Cyprinus carpio) using selected exotic feed ingredients. Aquaculture. 2014 418419:177-84.

23. Bustin SA, Benes V, Garson JA, Hellemans J, Huggett J, Kubista M, et al. The MIQE guidelines: minimum information for publication of quantitative real-time PCR experiments. Clin Chem. 2009 55:611-22.

24. Pfaffl MW, Horgan GW, Dempfle L. Relative expression software tool (REST@) for group-wise comparison and statistical analysis of relative expression results in real-time PCR. Nucleic Acids Res. 2002 30:e36.

25. Dimitroglou A, Merrifield D, Moate R, Davies S, Spring P, Sweetman J, et al. Dietary mannan oligosaccharide supplementation modulates intestinal microbial ecology and 
improves gut morphology of rainbow trout, Oncorhynchus mykiss (Walbaum). J Anim Sci. 2009 87:3226-34.

26. Miles A, Misra S, Irwin J. The estimation of the bactericidal power of the blood. J Hyg. 1938 38:732-49.

27. Ferguson RMW, Merrifield DL, Harper GM, Rawling MD, Mustafa S, Picchietti S, et al. The effect of Pediococcus acidilactici on the gut microbiota and immune status of ongrowing red tilapia (Oreochromis niloticus). J Appl Microbiol. 2010 109:851-62.

28. Al-Hisnawi A, Ringø E, Davies SJ, Waines P, Bradley G, Merrifield DL. First report on the autochthonous gut microbiota of brown trout (Salmo trutta Linnaeus). Aquac Res. 2014 46: 2962-2971.

29. Muyzer G, De Waal EC, Uitterlinden AG. Profiling of complex microbial populations by denaturing gradient gel electrophoresis analysis of polymerase chain reaction-amplified genes coding for 16S rRNA. Appl Environ Microbiol. 1993 59:695-700.

30. Merrifield DL, Güroy D, Güroy B, Emery MJ, Llewellyn CA, Skill S, et al. Assessment of Chlorogloeopsis as a novel microbial dietary supplement for red tilapia (Oreochromis niloticus). Aquaculture. 2010 299:128-33.

31. Giannenas I, Karamaligas I, Margaroni M, Pappas I, Mayer E, Encarnação P, et al. Effect of dietary incorporation of a multi-strain probiotic on growth performance and health status in rainbow trout (Oncorhynchus mykiss). Fish Physiol Biochem. 2015 41:119-28.

32. Lara-Flores M, Olvera-Novoa MA, Guzmán-Méndez BzE, López-Madrid W. Use of the bacteria Streptococcus faecium and Lactobacillus acidophilus, and the yeast Saccharomyces cerevisiae as growth promoters in Nile tilapia (Oreochromis niloticus). Aquaculture. 2003 216:193-201.

33. Mehrim A. Effect of dietary supplementation of Biogen (commercial probiotic) on mono-sex Nile tilapia Oreochromis niloticus under different stocking densities. Journal of Fisheries Aquat Sci. 2009 4:261-73. 
34. Jatobá A, Vieira Fd, Buglione-Neto C, Mouriño' J, Silva BC, Seiftter W, et al. Diet supplemented with probiotic for Nile tilapia in polyculture system with marine shrimp. Fish Physiol Biochem. 2011 37:725-32.

35. Abumourad I, Abbas W, Awaad E, Authman M, El-Sahfei K, Sharaf O, et al. Evaluation of Lactobacillus plantarum as a probiotic in aquaculture: Emphasis on growth performance and innate immunity. J Appl Sci Res. 2013 9:572-82.

36. Standen BT, Rodiles A, Peggs DL, Davies SJ, Santos GA, Merrifield DL. Modulation of the intestinal microbiota and morphology of tilapia, Oreochromis niloticus, following the application of a multi-species probiotic. Appl Microbiol Biotechnol. 2015 99: 8403-8417.

37. Aly SM, Abdel-Galil Ahmed Y, Abdel-Aziz Ghareeb A, Mohamed MF. Studies on Bacillus subtilis and Lactobacillus acidophilus, as potential probiotics, on the immune response and resistance of Tilapia nilotica (Oreochromis niloticus) to challenge infections. Fish Shellfish Immunol. 2008 25:128-36.

38. Norouzitallab P, Baruah K, Muthappa DM, Bossier P. Non-lethal heat shock induces HSP70 and HMGB1 protein production sequentially to protect Artemia franciscana against Vibrio campbellii. Fish Shellfish Immunol. 2015 42:395-9.

39. Basu N, Todgham AE, Ackerman PA, Bibeau MR, Nakano K, Schulte PM, et al. Heat shock protein genes and their functional significance in fish. Gene. 2002 295:173-83.

40. Avella MA, Gioacchini G, Decamp O, Makridis P, Bracciatelli C, Carnevali O. Application of multi-species of Bacillus in sea bream larviculture. Aquaculture. 2010 305:129.

41. Avella MA, Olivotto I, Silvi S, Carnevali O. Effect of dietary probiotics on clownfish: a molecular approach to define how lactic acid bacteria modulate development in a marine fish. Am J of Physiol-Reg I. 2010 298:R359-R71. 
42. Avella MA, Olivotto I, Silvi S, Ribecco C, Cresci A, Palermo F, et al. Use of Enterococcus faecium to improve common sole (Solea solea) larviculture. Aquaculture. 2011 315:384-93.

43. Voll RE, Herrmann M, Roth EA, Stach C, Kalden JR, Girkontaite I. Immunosuppressive effects of apoptotic cells. Nature. 1997 390:350-1.

44. Ring $\varnothing$ E, Myklebust R, Mayhew TM, Olsen RE. Bacterial translocation and pathogenesis in the digestive tract of larvae and fry. Aquaculture. 2007 268:251-64.

45. Takeuchi O, Hoshino K, Kawai T, Sanjo H, Takada H, Ogawa T, et al. Differential roles of TLR2 and TLR4 in recognition of Gram-negative and Gram-positive bacterial cell wall components. Immunity. 1999 11:443-51.

46. Basu M, Swain B, Sahoo B, Maiti N, Samanta M. Induction of toll-like receptor TLR2, and MyD88-dependent TLR- signaling in response to ligand stimulation and bacterial infections in the Indian major carp, mrigal (Cirrhinus mrigala). Mol Biol Rep. 2012 39:601528.

47. Perez-Sanchez T, Balcazar JL, Merrifield DL, Carnevali O, Gioacchini G, De Blas I, et al. Expression of immune-related genes in rainbow trout (Oncorhynchus mykiss) induced by probiotic bacteria during Lactococcus garvieae infection. Fish Shellfish Immunol. 2011 31:196-201.

48. Salinas I, Abelli L, Bertoni F, Picchietti S, Roque A, Furones D, et al. Monospecies and multispecies probiotic formulations produce different systemic and local immunostimulatory effects in the gilthead seabream (Sparus aurata L.). Fish Shellfish Immunol. 2008 25:114-23.

49. Picchietti S, Fausto AM, Randelli E, Carnevali O, Taddei AR, Buonocore F, et al. Early treatment with Lactobacillus delbrueckii strain induces an increase in intestinal T-cells and granulocytes and modulates immune-related genes of larval Dicentrarchus labrax (L.). Fish Shellfish Immunol. 2009 26:368-76. 
50. Pirarat N, Kobayashi T, Katagiri T, Maita M, Endo M. Protective effects and mechanisms of a probiotic bacterium Lactobacillus rhamnosus against experimental Edwardsiella tarda infection in tilapia (Oreochromis niloticus). Vet Immunol Immunop. 2006 113:339-47. 


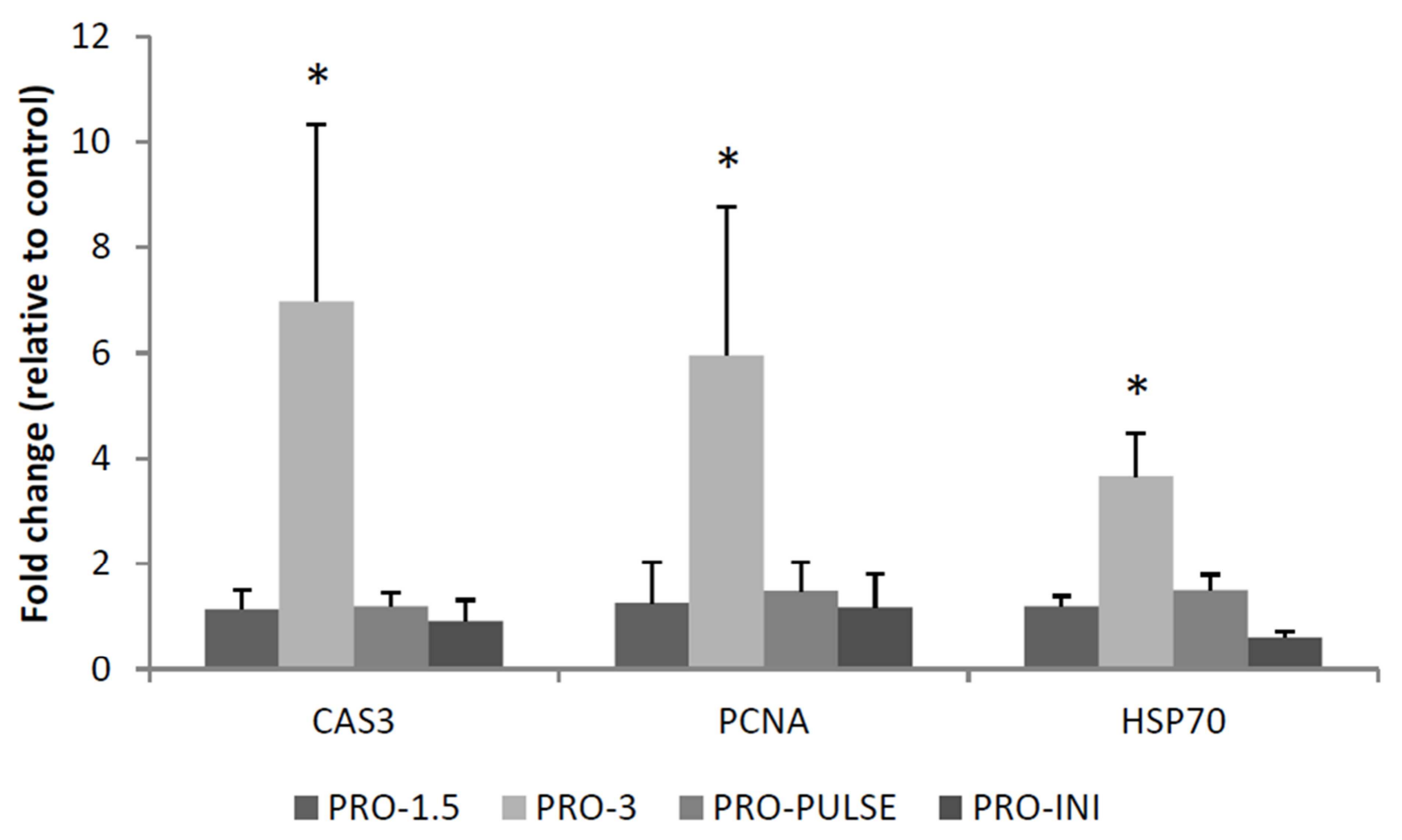



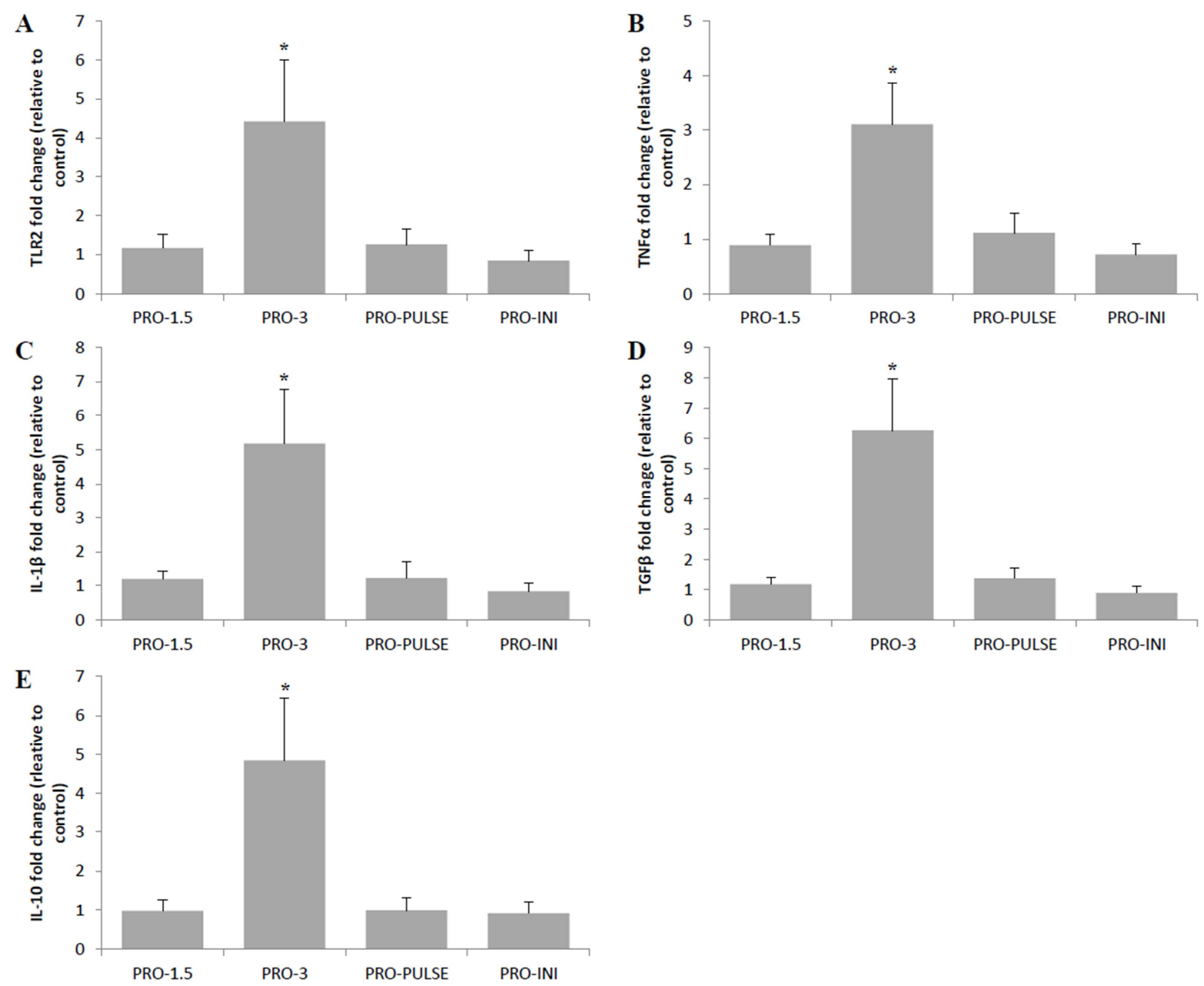


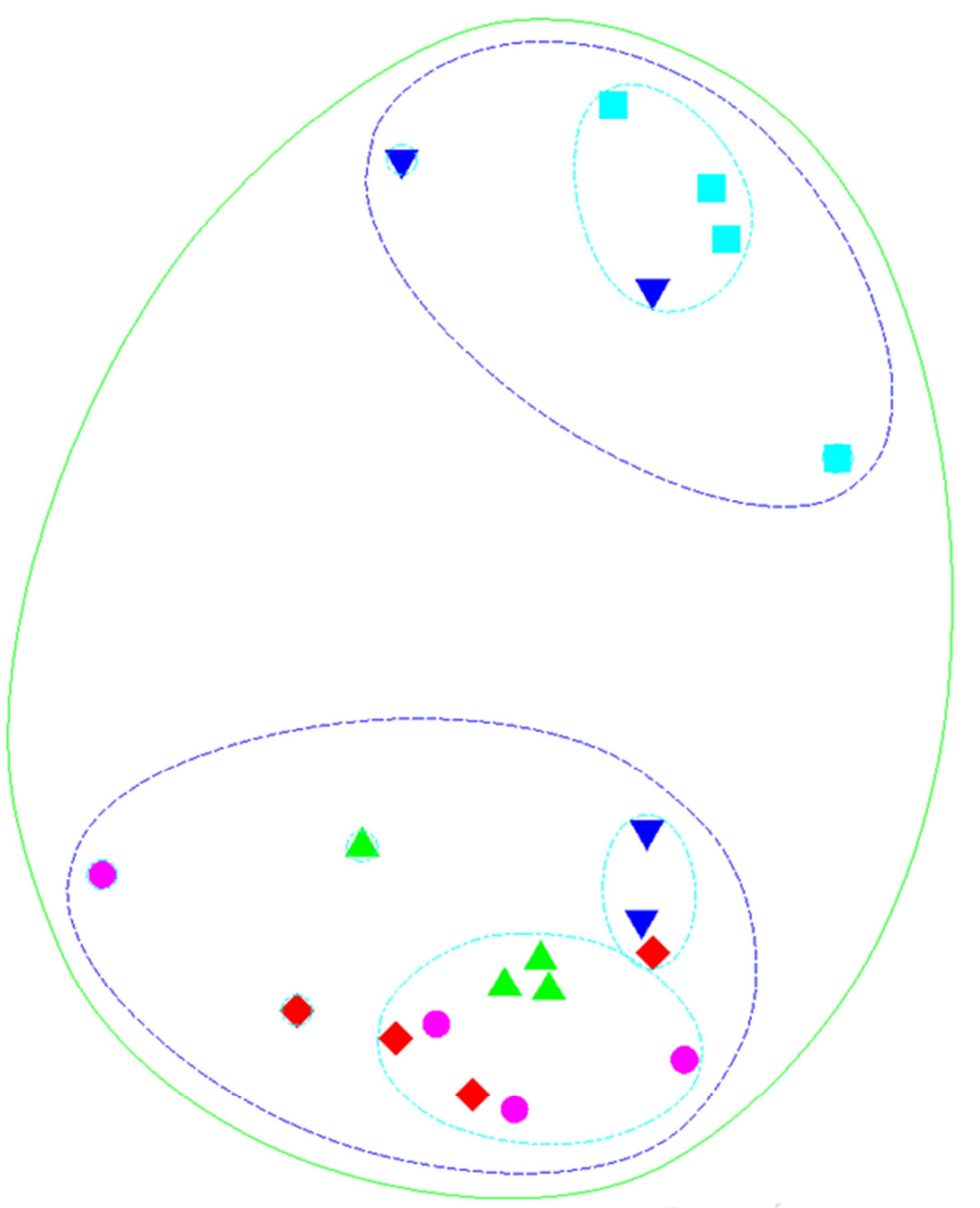

2D Stress: 0.07

Treatment

$\triangle \mathrm{CON}$

$\checkmark \mathrm{PRO}-1.5$

PRO-3

PRO-PULSE

- PRO-INI

Similarity 40

60

80 
Highlights for manuscript "Dietary administration of a commercial mixed-species probiotic improves growth performance and modulates the intestinal immunity of tilapia, Oreochromis niloticus"

- $\quad$ AquaStar $^{\circledR}$ Growout improves the growth performance of juvenile tilapia.

- AquaStar $^{\circledR}$ Growout can augment mucosal tolerance.

- AquaStar $^{\circledR}$ Growout improves immune readiness. 